\title{
Perubahan Tutupan Lahan Setelah 14 Tahun Bencana Tsunami (Studi Kasus di Kecamatan Baitussalam)
}

\author{
(Land Cover Changes after 14 years of the Tsunami \\ Case Study at Kecamatan Baitussalam)
}

\author{
Nadya Faizah', Muhammad Rusdi ${ }^{1}$, Sugianto $^{1 *}$ \\ ${ }^{1}$ Program Studi Ilmu Tanah, Fakultas Pertanian, Universitas Syiah Kuala
}

\begin{abstract}
Abstrak. Perubahan tutupan lahan mengakibatkan beberapa penggunaan lahan menjadi berubah, terutama pada lahan pertanian yang berubah menjadi non-pertanian. Perubahan penggunaan lahan saat ini sudah sering terjadi di beberapa daerah terutama pada lahan pertanian yang berubah menjadi lahan non-pertanian. Pasca Tsunami daerah yang terkena bencana dilakukan rehabilitasi dan rekontruksi, semua aktivitas tersebut berdampak kepada perubahan tutupan lahan. Perubahan tutupan lahan diperoleh dari overlay dengan kaedah union mulai dari tahun 2004 hingga tahun 2018. Hasil analisis menunjukkan bahwa perubahan tutupan lahan selama kurun waktu 14 tahun pasca Tsunami terbesar terjadi pada pemukiman, yaitu mengalami peningkatan sebesar 550,14 ha $(76,96 \%)$. sedangkan Perubahan tutupan lahan terkecil yaitu semak belukar sebesar 66,41 ha $(5,06 \%)$.
\end{abstract}

Kata Kunci: Perubahan, tutupan lahan, Tsunami

\begin{abstract}
Changes in land cover have caused some land use to change, especially on agricultural land that has turned into non-agricultural land. Post-tsunami areas affected by rehabilitation and reconstruction, all of these activities have an impact on land cover change. Changes in land cover were obtained from overlays with the unification method from 2004 to 2018. The results of the analysis showed that changes in land cover for 14 years after the Tsunami occurred mostly in settlements, which increased by 550.14 ha $(76.96 \%)$. while the smallest land cover change is shrubs covering an area of 66.41 ha $(5.06 \%)$.
\end{abstract}

Keywords: Changes, land cover, land use, tsunami

\section{PENDAHULUAN}

Bencana Besar terjadi pada 26 desember 2004 yang menghancurkan wilayah aceh dan sebagian pesisir barat. Akibatnya banyak terjadi kerusakan dan berkurangnya beberapa tutupan lahan (Rahmi et. al, 2017). Tidak hanya itu, tsunami juga mempengaruhi garis pantai, sehingga berubah dari beberapa meter menjadi seratus meter (Sugianto et al, 2017). Perubahan tutupan lahan mengakibatkan beberapa penggunaan lahan menjadi berubah pula, terutama pada lahan pertanian yang berubah menjadi non-pertanian.

Pasca Tsunami kota Banda Aceh telah melakukan rehabilitasi dan rekontruksi pada infrastruktur kota, semua aktivitas kegiatan tersebut berdampak pada perubahan tutupan lahan. Penyimpangan penggunaan lahan dari RTRW telah terjadi di Kabupaten Aceh Besar akibat rehabilitasi dan rekontruksi setelah tsunami di Kabupaten Aceh Besar. Hal ini sesuai dengan hasil penelitian penelitian (Arbi, 2016) di Kecamatan Kuta Baro yang menunjukkan telah terjadi penyimpangan penggunaan lahan eksisting tahun 2015 dari arahan RTRW Kabupaten Aceh Besar tahun 2012-2032 seluas 140.58 ha atau 2,30\% dari total luas Kecamatan Kuta Baro. Selanjutnya hasil penelitian (Sahputra, 2017) menunjukkan bahwa di Kecamatan Darul Imarah juga telah terjadi penggunaan lahan yang tidak sesuai dengan arahan RTRW Kabupaten Aceh Besar tahun 2012-2032 seluas 125,78 ha atau 5,17\% dari total luas Kecamatan Darul Imarah. 
Sehubungan dengan uraian sebelumnya, Kecamatan Baitussalam merupakan kecamatan yang terkena dampak bencana tsunami. kecamatan ini terletak di wilayah pesisir dan berada di pinggir Kota Banda Aceh. Sehingga diperlukan kajian untuk mengetahui perubahan tutupan lahan yang terjadi selama rentan waktu 14 tahun setelah tsunami.

\section{METODE PENELITIAN}

Penelitian ini dilaksanakan di Laboratorium Penginderaan Jauh dan Kartografi Fakultas Pertanian Universtas Syiah Kuala dengan wilayah kajian Kecamatan Baitussalam. Alat yang digunakan perangkat laptop, printer, kamera, global positioning system (GPS), Software ArcGIS 10.1, dan Google Earth Pro. Bahan yang digunakan pada penelitian ini yaitu peta administrasi Kabupaten Aceh Besar, Google Earth Imagery tahun 2004, dan 2018.

Sistem klasifikasi merujuk kepada Kementrian Lingkungan Hidup dan Kehutanan (KLHK) tahun 2015. Metode yang digunakan pada penelitian ini yaitu metode deskriptif kuantitatif, sedangakan analisis data digunakan dengan metode overlay dengan kaedah union. tahapan persiapan, pra pengolahan citra, pengolahan citra, kegiatan lapangan dan analisis data.

Pengamatan dilapangan dilakukan untuk mencocokkan data yang telah dianalisis sebelumnya dengan keadaan di lapangan. Pengamatan lapangan yang dilakukan dengan menggunakan bantuan GPS (Global Positioning System). Data yang telah dicocokkan dengan keadaan dilapangan kemudian dianalisis kembali untuk menghasilkan data yang lebih akurat. Berikut diagram alir pelaksanaan penelitian dapat dilihat pada Gambar 1.

\section{HASIL DAN PEMBAHASAN}

Hasil klasifikasi visual on screen dan pengamatan lapangan (ground check) didapat delapan kelas penggunaan lahan di Kecamatan Baitussalam pada tahun 2004 dan 2018. Secara detail dapat dilihat pada Tabel 1 dan 2. Berdasarkan Tabel 1 diperoleh kelas penggunaan yang paling besar di Kecamatan Baitussalam pada tahun 2004 adalah lahan terbuka (kerusakan tsunami) yaitu seluas 939,76 ha $(46,04 \%)$, sedangkan penggunaan lahan yang paling kecil adalah sawah yaitu seluas 31,89 ha $(1,56 \%)$. Sedangkan berdasarkan Tabel 2 diperoleh penggunaan yang paling besar pada tahun 2018 adalah permukiman yaitu seluas 632,47 ha $(30,98 \%)$ dan penggunaan lahan yang paling kecil adalah rawa yaitu seluas 21,01 ha $(1,03 \%)$.

Perubahan Tutupan Lahan Setelah 14 Tahun Bencana Tsunami (Studi Kasus di Kecamatan Baitussalam) (Nadya Faizah, Muhammad Rusdi, Sugianto)

Jurnal Ilmiah Mahasiswa Pertanian Unsyiah, Vol. 4, No. 1, Februari 2019 : 699-707 


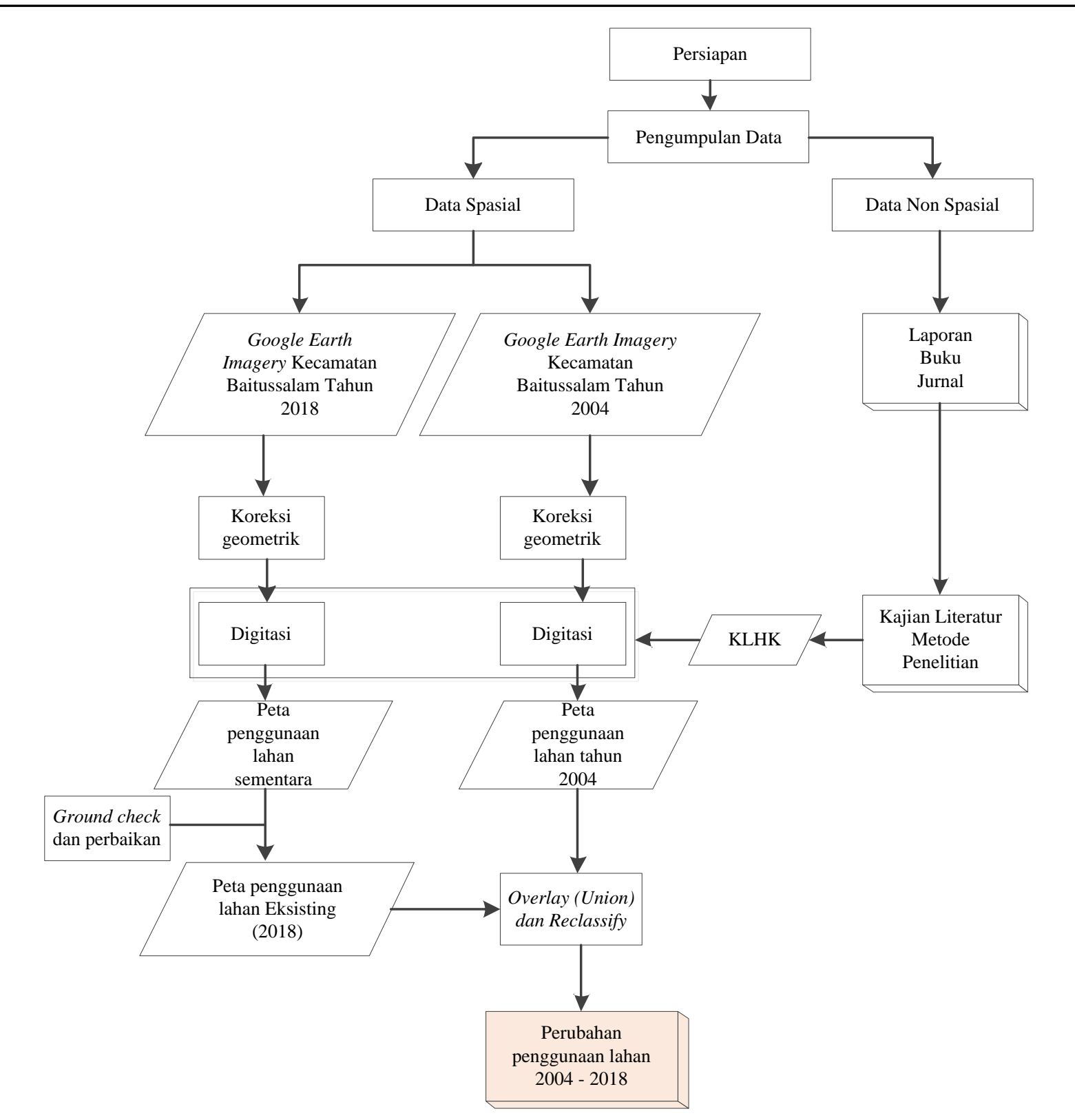

Gambar 1. Diagram Alir Penelitian

Perubahan Tutupan Lahan Setelah 14 Tahun Bencana Tsunami (Studi Kasus di Kecamatan Baitussalam) (Nadya Faizah, Muhammad Rusdi, Sugianto)

Jurnal Ilmiah Mahasiswa Pertanian Unsyiah, Vol. 4, No. 1, Februari 2019 : 699-707 
Tabel 1. Penggunaan Lahan di Kecamatan Baitussalam Tahun 2004

\begin{tabular}{clrr}
\hline No & Penggunaan Lahan 2004 & Hektar & Persentase \\
\hline 1 & Lahan terbuka (Kerusakan Tsunami) & 939,76 & 46,04 \\
2 & Lahan Terbuka & 43,42 & 2,13 \\
3 & Permukiman & 82,33 & 4,03 \\
4 & Pertanian Lahan Kering & 122,79 & 6,02 \\
5 & Rawa & 64,96 & 3,18 \\
6 & Sawah & 31,89 & 1,56 \\
7 & Semak Belukar & 623,19 & 30,53 \\
8 & Tambak & 132,98 & 6,51 \\
\hline & Total & $\mathbf{2 0 4 1 , 3 3}$ & $\mathbf{1 0 0 , 0 0}$ \\
\hline
\end{tabular}

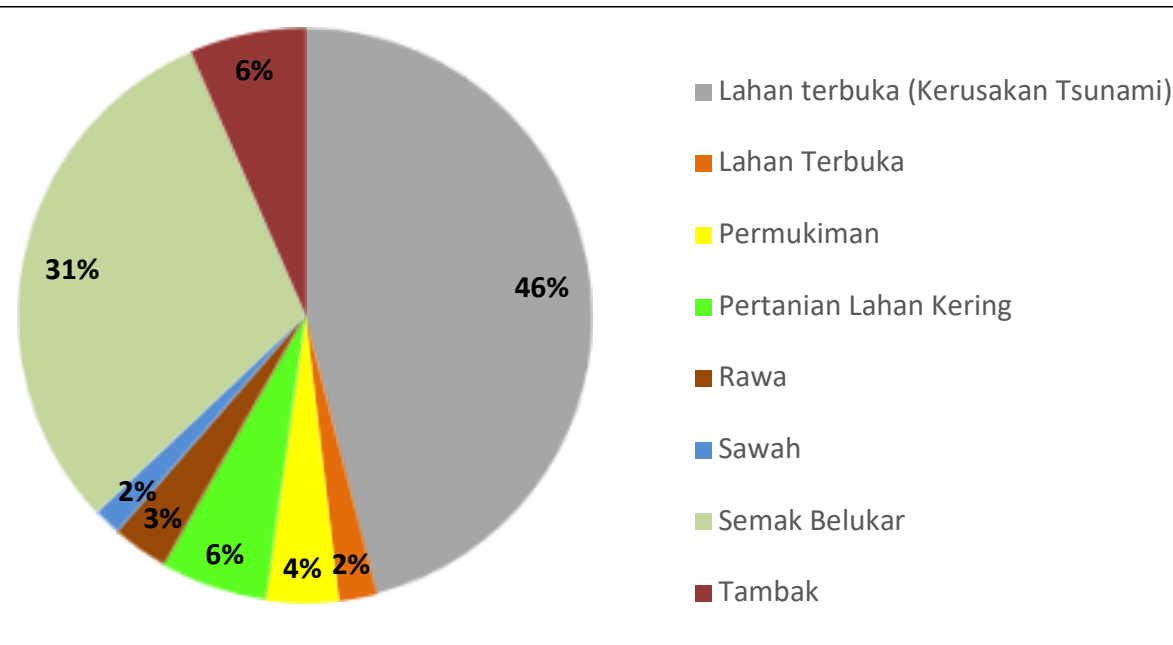

Gambar 2. Persentase Luas Penggunaan Lahan Tahun 2004 di Kecamatan Baitussalam

Tabel 2. Penggunaan Lahan di Kecamatan Baitussalam Tahun 2018

\begin{tabular}{clrr}
\hline No & Penggunaan Lahan 2018 & Hektar & Persentase \\
\hline 1 & Hutan Mangrove & 69,27 & 3,39 \\
2 & Lahan Terbuka & 43,32 & 2,12 \\
3 & Permukiman & 632,47 & 30,98 \\
4 & Pertanian Lahan Kering & 121,56 & 5,95 \\
5 & Rawa & 21,01 & 1,03 \\
6 & Sawah & 31,04 & 1,52 \\
7 & Semak Belukar & 689,60 & 33,78 \\
8 & Tambak & 433,05 & 21,21 \\
\hline & Total & $\mathbf{2 0 4 1 , 3 3}$ & $\mathbf{1 0 0 , 0 0}$ \\
\hline
\end{tabular}

Perubahan Tutupan Lahan Setelah 14 Tahun Bencana Tsunami (Studi Kasus di Kecamatan Baitussalam) (Nadya Faizah, Muhammad Rusdi, Sugianto)

Jurnal Ilmiah Mahasiswa Pertanian Unsyiah, Vol. 4, No. 1, Februari 2019 : 699-707 


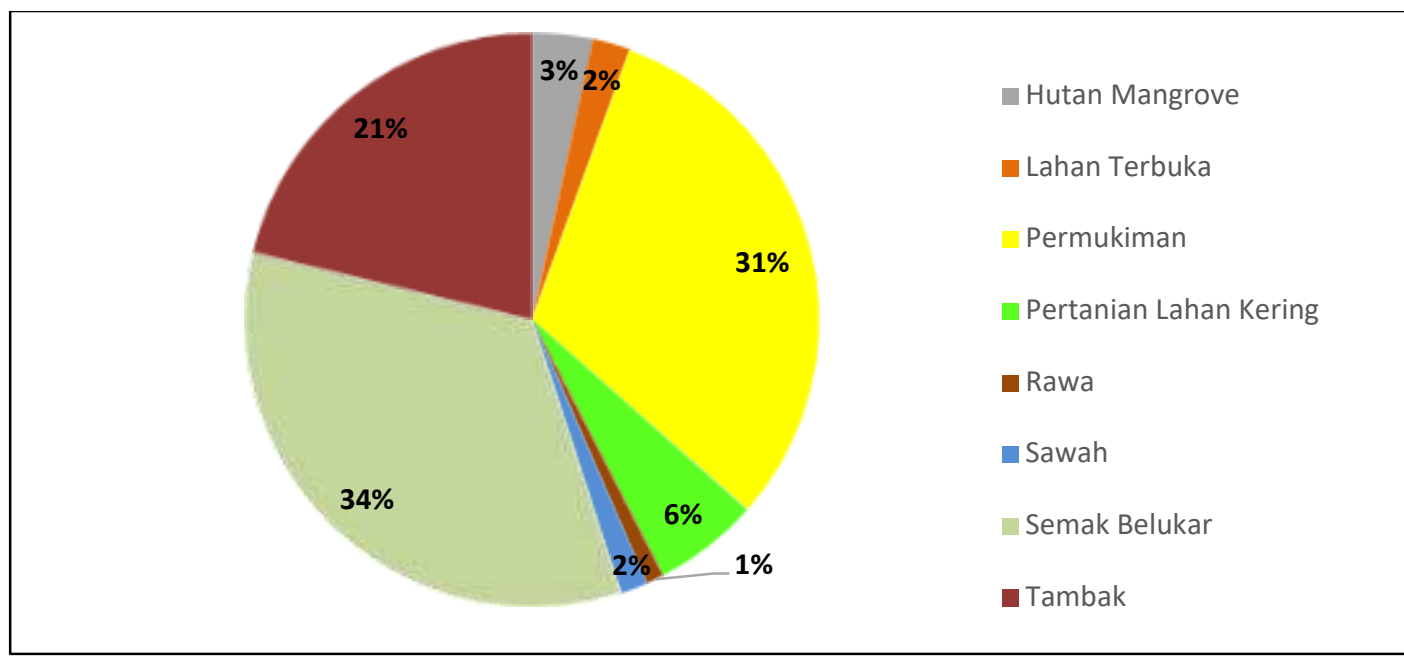

Gambar 3. Persentase Luas Penggunaan Lahan Tahun 2018 di Kecamatan Baitussalam

Kelas penggunaan lahan yang mengalami peningkatan terbesar dari tahun 2004 hingga 2018 di Kecamatan Baitussalam adalah hutan mangrove yaitu seluas 69,27 ha atau (100\%) dan permukiman yaitu seluas 550,14 ha atau (76,96\%). Tercatat 53.900 ha hutan mangrove yang musnah di Kabupaten Aceh Besar setelah terjadinya bencana gempa dan tsunami yang melanda Provinsi Aceh pada tahun 2004 (Wibisono, 2006). Kecamatan Baitussalam merupakan salah satu lokasi yang dilakukan upaya rehabilasi guna mengembalikan dan memulihkan ekosistem mangrove yang telah rusak akibat bencana tsunami tahun 2004 (Zainabun et. al, 2011). Disajikan kenampakan dilapangan hutan mangrove di Kecamatan Baitussalam pada Gambar 2.

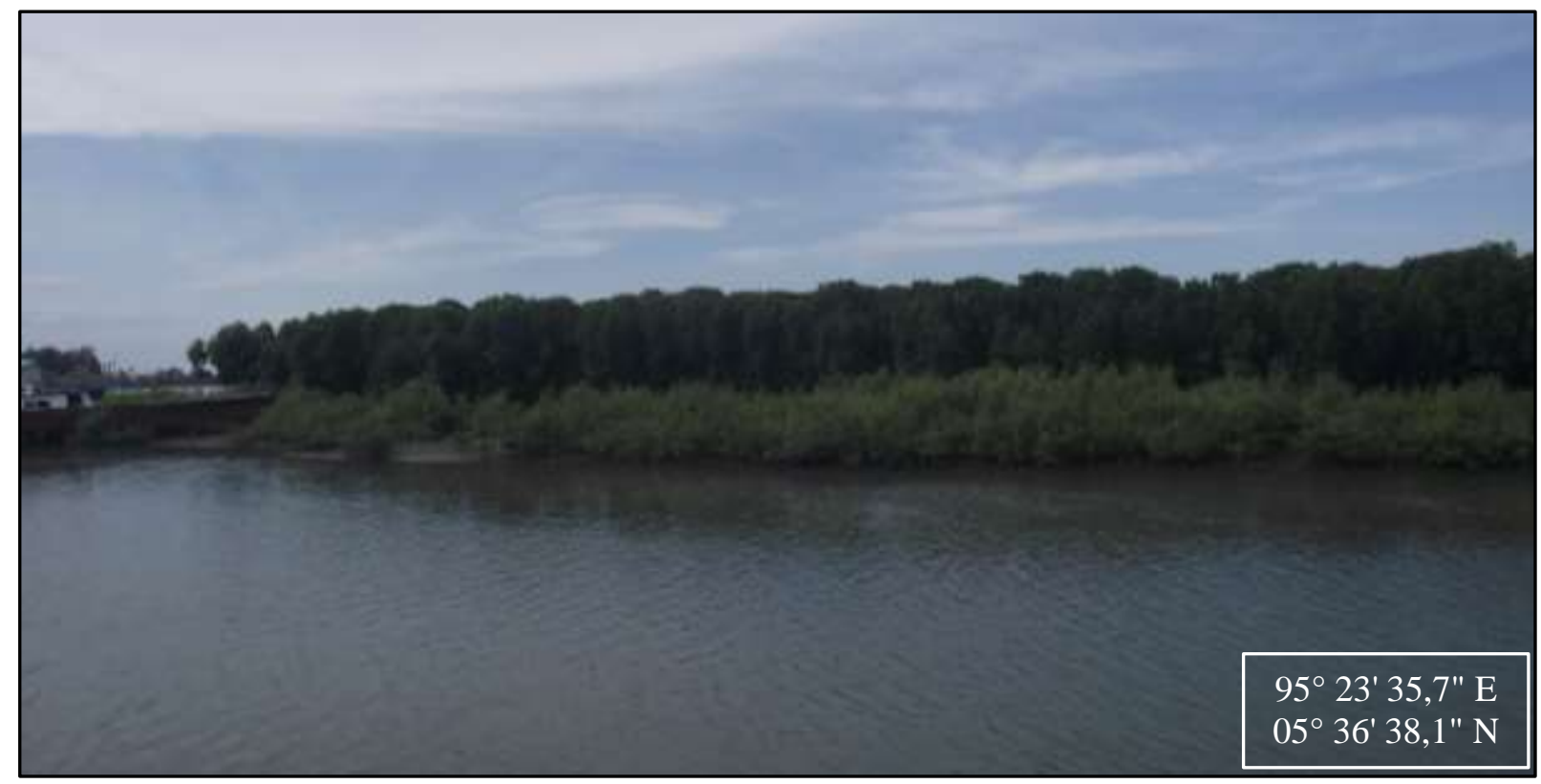

Gambar 4. Hutan Mangrove di Kecamatan Baitussalam pada tahun 2018

Perubahan Tutupan Lahan Setelah 14 Tahun Bencana Tsunami (Studi Kasus di Kecamatan Baitussalam) (Nadya Faizah, Muhammad Rusdi, Sugianto)

Jurnal Ilmiah Mahasiswa Pertanian Unsyiah, Vol. 4, No. 1, Februari 2019 : 699-707 


\section{Perubahan Penggunaan Lahan di Kecamatan Baitussalam}

Perubahan penggunaan lahan di Kecamatan Baitussalam dalam kurun waktu 14 tahun ialah seluas $1.158,52$ ha $(10,72 \%)$ sedangkan penggunaan lahan yang tidak berubah adalah seluas 882,82 ha $(43,25 \%)$. Perubahan penggunaan lahan yang sangat besar terjadi adalah pada lahan terbuka (kerusakan tsunami) menjadi permukiman yaitu seluas 441,29 ha $(21,62 \%)$ dan penggunaan lahan yang paling kecil terjadi perubahan adalah pertanian lahan kering menjadi hutan mangrove yaitu seluas 1,00 ha $(0,05 \%)$. Perubahan penggunaan lahan disajikan pada Tabel 4. Secara spasial perubahan penggunaan lahan di Kecamatan Baitussalam dapat dilihat pada Gambar 5.

Tabel 4. Perubahan penggunaan Lahan di Kecamatan Baitussalam Tahun 2004 - 2009

\begin{tabular}{|c|c|c|c|c|}
\hline Penggunaan Lahan 2004 & Penggunaan Lahan 2009 & Hektar & Persentase & Keterangan \\
\hline 1 & 2 & 3 & 4 & 5 \\
\hline Lahan Terbuka & Lahan Terbuka & 14,08 & 0,69 & \\
\hline Permukiman & Permukiman & 82,33 & 4,03 & \\
\hline Pertanian Lahan Kering & Pertanian Lahan Kering & 94,68 & 4,64 & \\
\hline Rawa & Rawa & 10,17 & 0,50 & Tidak Berubah \\
\hline Sawah & Sawah & 29,93 & 1,47 & \\
\hline Semak Belukar & Semak Belukar & 594,10 & 29,10 & \\
\hline Tambak & Tambak & 57,52 & 2,82 & \\
\hline \multirow{8}{*}{ Kerusakan Tsunami } & Hutan Mangrove & 28,39 & 1,39 & \\
\hline & Lahan Terbuka & 21,50 & 1,05 & \\
\hline & Permukiman & 441,29 & 21,62 & \\
\hline & Pertanian Lahan Kering & 2,60 & 0,13 & \\
\hline & Rawa & 7,69 & 0,38 & \\
\hline & Sawah & 1,11 & 0,05 & \\
\hline & Semak Belukar & 76,06 & 3,73 & \\
\hline & Tambak & 361,14 & 17,69 & \\
\hline \multirow{3}{*}{ Lahan Terbuka } & Permukiman & 26,63 & 1,30 & \\
\hline & Pertanian Lahan Kering & 1,08 & 0,05 & \\
\hline & Tambak & 1,63 & 0,08 & \\
\hline \multirow{5}{*}{ Pertanian Lahan Kering } & Hutan Mangrove & 1,00 & 0,05 & \\
\hline & Lahan Terbuka & 2,66 & 0,13 & Berubah \\
\hline & Permukiman & 16,93 & 0,83 & \\
\hline & Semak Belukar & 4,99 & 0,24 & \\
\hline & Tambak & 2,52 & 0,12 & \\
\hline \multirow{4}{*}{ Rawa } & Permukiman & 28,51 & 1,40 & \\
\hline & Pertanian Lahan Kering & 1,59 & 0,08 & \\
\hline & Semak Belukar & 14,45 & 0,71 & \\
\hline & Tambak & 10,24 & 0,50 & \\
\hline
\end{tabular}

Perubahan Tutupan Lahan Setelah 14 Tahun Bencana Tsunami (Studi Kasus di Kecamatan Baitussalam) (Nadya Faizah, Muhammad Rusdi, Sugianto)

Jurnal Ilmiah Mahasiswa Pertanian Unsyiah, Vol. 4, No. 1, Februari 2019 : 699-707 
Tabel 4. Lanjutan

\begin{tabular}{llrr}
\hline & \multicolumn{1}{c}{2} & \multicolumn{1}{c}{3} & \multicolumn{1}{c}{4} \\
\hline Sawah & Permukiman & 1,96 & 0,10 \\
\hline \multirow{3}{*}{ Semak Belukar } & Lahan Terbuka & 5,08 & 0,25 \\
& Permukiman & 19,59 & 0,96 \\
& Pertanian Lahan Kering & 4,42 & 0,22 \\
\hline Tambak & Hutan Mangrove & 39,88 & 1,95 \\
& Permukiman & 15,67 & 0,77 \\
& Pertanian Lahan Kering & 16,75 & 0,82 \\
& Rawa & 3,16 & 0,15 \\
\hline
\end{tabular}

\section{SIMPULAN DAN SARAN}

Perubahan penggunaan lahan di Kecamatan Baitussalam dalam kurun waktu 14 tahun ialah seluas $1.158,52$ ha $(10,72 \%)$ sedangkan penggunaan lahan yang tidak berubah adalah seluas 882,82 ha $(43,25 \%)$. Tutupan lahan yang sangat banyak mengalami penambahan luas yaitu pemukiman seluas 550,14 ha atau mengalami peningkatan sebanyak $76,96 \%$. Sedangkan penggunaan lahan yang sedikit mengalami pertambahan luas adalah semak belukar yaitu seluas 66,41 ha atau mengalami peningkatan sebanyak 5,06\%. Diharapkan adanya penelitian lanjutan yang dilakukan untuk seluruh kecamatan yang termasuk ke dalam kawasan yang terkecana bencana Tsunami. 

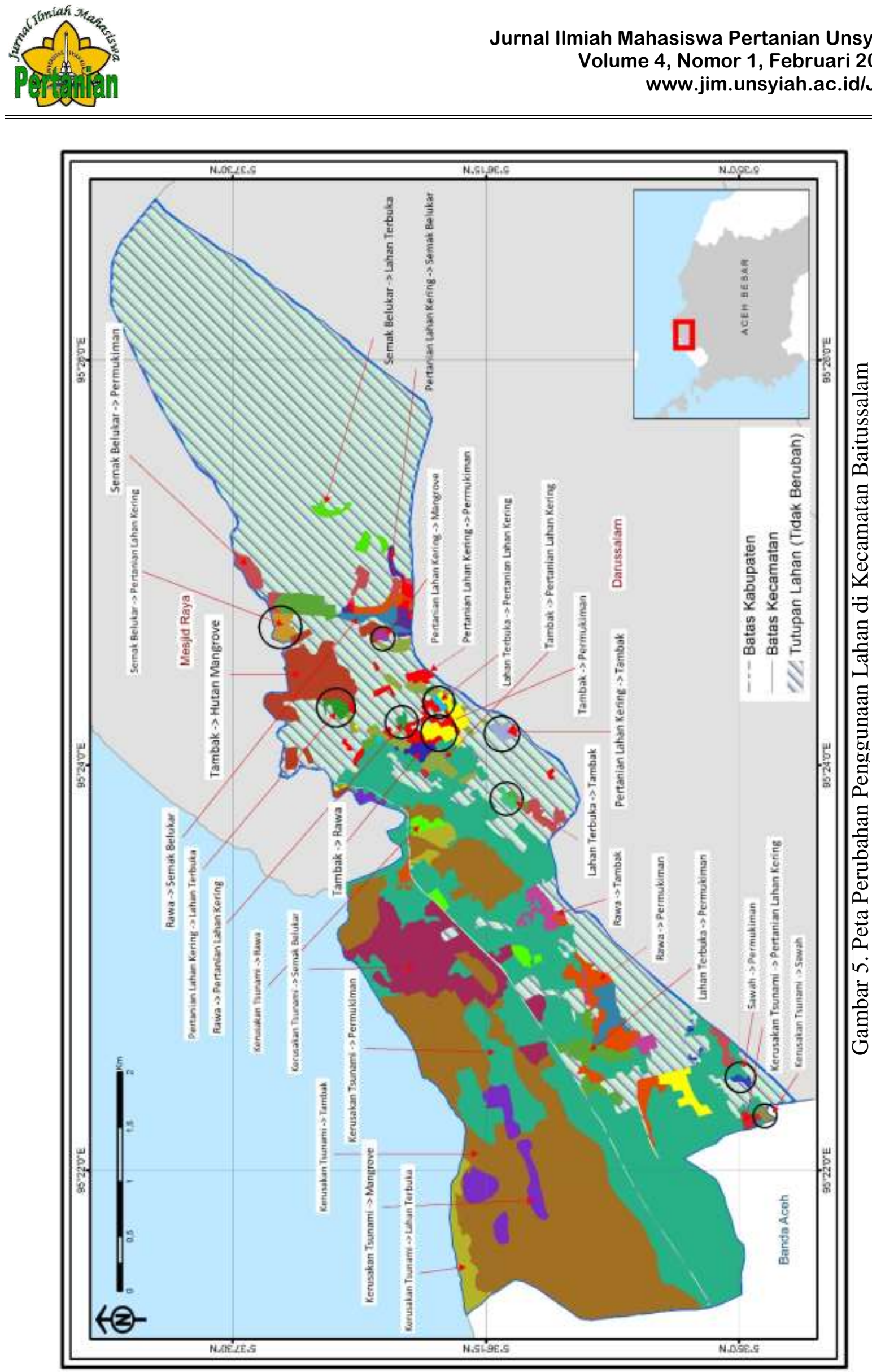

Perubahan Tutupan Lahan Setelah 14 Tahun Bencana Tsunami (Studi Kasus di Kecamatan Baitussalam) (Nadya Faizah, Muhammad Rusdi, Sugianto)

Jurnal Ilmiah Mahasiswa Pertanian Unsyiah, Vol. 4, No. 1, Februari 2019 : 699-707 


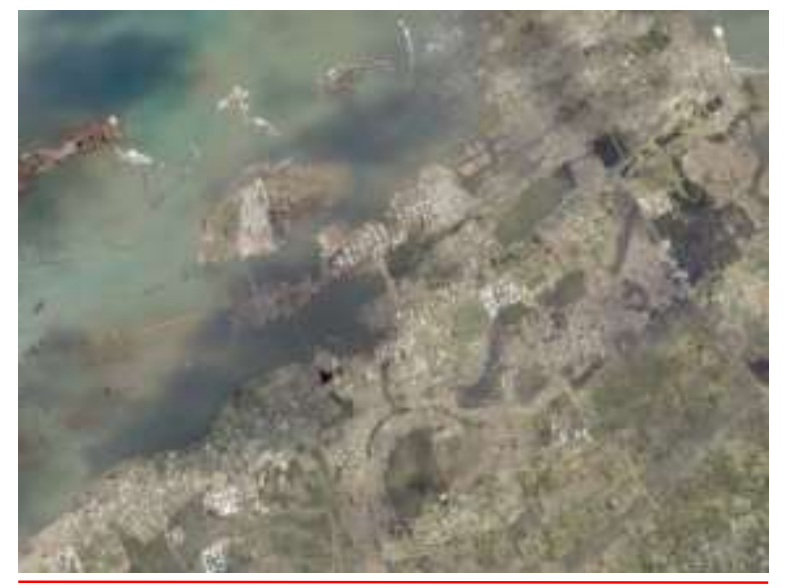

a. Kenampakan Citra Tahun 2004

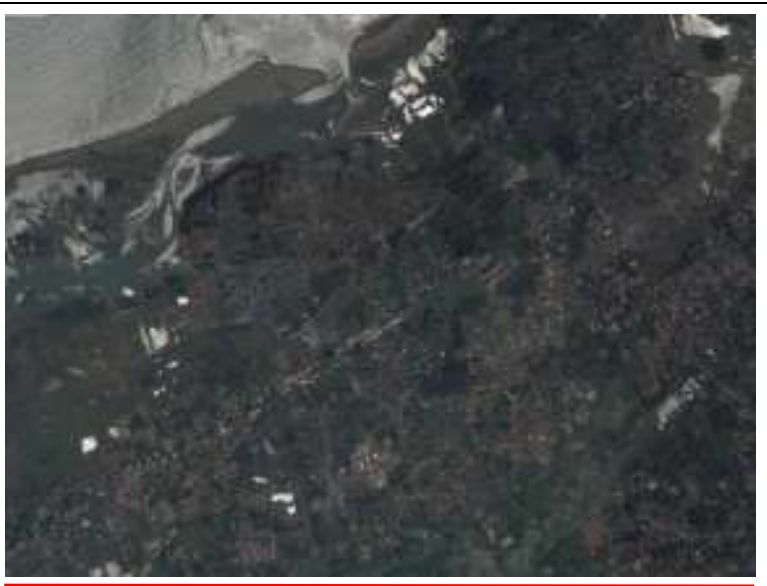

b. Kenampakan Citra Tahun 2004

Gambar 6. Perubahan Citra Temporal di Kecamatan Baitussalam Kabupaten Aceh Besar

\section{DAFTAR PUSTAKA}

Apriyana, M. 2015. Dampak alih fungsi lahan situ kuru terhadap lingkungan di Kelurahan Cempaka Putih Kecamatan Ciputat Timur. Skripsi. Jurusan Pendidikan Ilmu Pengetahuan Sosial Fakultas Ilmu Tarbiyah Dan Keguruan Universitas Islam Negeri Syarif Hidayatullah, Jakarta.

Arbi, M. 2016. Analisis penggunaan lahan eksisting berdasarkan rencana tata ruang wilayah (RTRW) di Kecamatan Kuta Baro Kabupaten Aceh Besar. Skripsi. Program Studi Agroteknologi Fakultas Pertanian Universitas Syiah Kuala, Banda Aceh.

KLHK. 2015. Peraturan Direktur Jenderal Planologi Kehutanan Tentang Pedoman Pemantauan Penutupan Lahan. Jakarta.

Rahmi, M M., Sugianto dan Faisal. 2017. Analisis Perubahan Lahan Tambak di Kawasan Pesisir Kota Banda Aceh. Prosiding Seminar Nasional Pascasarjana (SNP) Unsyiah.

Sahputra, D. 2017. Analisis penggunaan lahan eksisting berdasarkan rencana tata ruang wilayah (RTRW) di Kecamatan Darul Imarah Kabupaten Aceh Besar. Program Studi Ilmu Tanah Fakultas Pertanian Universitas Syiah Kuala, Banda Aceh.

Sugianto., Heriansyah., Darusman. 2018. Shoreline change after 12 years of tsunami in Banda Aceh, Indonesia: a multi-resolution, multi-temporal satelite data and GIS approach. ICTROPS. Hal 1-8.

Wibisono, I. T. C., dan I. N. N. Suryadiputra. 2016. Hasil pembelajaran atas upaya-upaya restorasi ekosistem pesisir sejak peristiwa tsunami di Aceh dan Nias. Wetlands International-Indonesia. Bogor.

Zainabun., Djuwita, S dan Diba, F. 2011. Rencana pengembangan wilayah zonasi mangrove untuk rehabilitasi lahan pasca tsunami di Kecamatan Baitussalam Kabupaten Aceh Besar. Agrista. Vol 15 No 1 Hal 10-14. 